Research Report No. 27/2007

\title{
Development and Tax Policy: Case Study of China
}

Jinyan Li

Osgoode Hall Law School of York University, JLi@osgoode.yorku.ca

Follow this and additional works at: http:// digitalcommons.osgoode.yorku.ca/clpe

\section{Recommended Citation}

Li, Jinyan, "Development and Tax Policy: Case Study of China" (2007). Comparative Research in Law \& Political Economy. Research Paper No. 27/2007.

http://digitalcommons.osgoode.yorku.ca/clpe/243 


\section{Comparative Research in Law \& Political Economy}

\section{J inyan Li}

Development and Tax Policy: Case Study of China

EDTORS: Peer Zumbansen (Osgoode Hall Law School, Toronto, Director, Comparative Research in Law and Political Economy, York University), J ohn W. Cioffi (University of California at Riverside), Lindsay Krauss (Osgoode Hall Law School, Toronto, Production Editor) 

CLPE Research Paper 27/2007

Vol. 03 No. 04 (2007)

\title{
Jinyan Li
}

\section{Development and Tax Policy: Case Study of China}

\begin{abstract}
This paper examines the role of tax policy in China's economic, social and legal development. With respect to economic development, the author examines the use of tax incentives in attracting foreign direct investment to China and assesses its impact on the development of China's market economy. In terms of social development, the author critically assesses the limited role of taxation in reducing disparities in social income and in promoting social policies. While the relationship between legal development and tax policy may not be as obvious, the author makes the case that tax policy has had a positive impact on the development rule-by-law in China. While China has never experienced a western style rule of law, Chinese tax laws are similar to western tax laws in terms of substantive and procedural rules. The author notes the possibility that a well-developed tax system may be the impetus for the development of rule of law in China.
\end{abstract}

Keywords: development, China, rule of law, tax policy, tax incentives, foreign direct investment, tax administration, taxpayers' rights, tax expenditures

JEL Classification: K34

Author Contact: Jinyan Li

Osgoode Hall Law School, York University

4700 Keele St., Toronto, ON, Canada M3J 1P3

Email: jinyanli@osgoode.yorku.ca 


\title{
Development and Tax Policy: Case Study of CHINA
}

\author{
Jinyan Li ${ }^{*}$
}

\section{INTRODUCTION}

Broadly understood, the concept of development has three dimensions: economic, social and legal. Over the past three decades, China has experienced remarkable economic development and less social and legal development. The gross domestic product (GDP) grew from CNY362,410 million in 1978 to CNY 13,687,590 million in 2004. ${ }^{1}$ In 2005, China was the world's fourth largest economy measured by the size of the GDP, the third largest trader, and one of the largest recipients of foreign direct investment. ${ }^{2}$ The average wage increased from CNY762 in 1980 to CNY14,040 in 2003. ${ }^{3}$ China has been successful in reducing poverty and improving some social indicators. ${ }^{4}$ But, income disparities have been rising rapidly in China. The Gini coefficient, a widely used measure for

\footnotetext{
* Professor of Law. Osgoode Hall Law School. York University, Toronto. The Author thanks Richard Bird, Neil Brooks, Rick Krever and Yoram Margalioth, as well as the participants at $1^{\text {st }}$ INTR Conference on Taxation and Development (3-5 November 2006) and the Faculty of Law, University of Toronto, The James Hausman Tax Law \& Policy Workshop series, March 2007 for their comments on an earlier version of this paper. She also thanks He Huang, an LL.M candidate at Osgoode Hall Law School, for her research assistance.

${ }^{1}$ China Statistical Year Book (2005). http://www.stats.gov.cn/tjsj/ndsj/2005/indexch.htm.

2 For a detailed discussion of FDI flows, see World Investment Report , http://www.unctad.org/Templates/Page.asp?intItemID=1485\&lang=1

${ }^{3}$ National Bureau of Statistics, Beijing, China. www.stats.gov.cn.

${ }^{4}$ See World Bank. 2005. China Leading Group on Poverty Alleviation and Development CDD Project. http://siteresources.worldbank.org; and UN Country Team China Occasional Paper, “Advancing Social Development in China: Contribution to the $11^{\text {th }}$ Five-Year

Plan. http://www.unchina.org/115plan/ENGLISH.pdf\#search=\%22social\%20development\%20 China\%22.
} 
inequality, rose from 0.25 in 1980 to an estimated 0.45 in $2005 .^{5}$ In the early 1990 s, the top $10 \%$ of the population held $40 \%$ of savings in China. By 2005, the top 5\% of the population own about $50 \%$ of the national savings. ${ }^{6}$ The Chinese legal system has been transformed from an ideology-based system to a regime that is more accommodating to the market. ${ }^{7}$ And yet, China does not have the rule of law. ${ }^{8}$

Tax policy has been an important instrument for the Chinese government. As in other countries, the government not only relies on taxation as its main source of revenue, but also a "leverage" in "regulating" economic and social activities. The role of tax policy in China's development is perhaps “unique” because China's experiment with development is unique in many ways. It is a socialist country governed by the Communist Party. The Chinese leadership has resisted the advice of international experts to go for big bang economic reforms in favour of a more gradual, pragmatic

5 Bert Hoffman. 2006. Access to Opportunity Eases Income Inequality. China Daily (2006-01-20). $\quad$ http://www.chinadaily.com.cn/chinagate/doc/200601/20/content_514069.htm); and Shenggan Fan and Connie Chan-Kang. 2005. Road Development, Economic Growth, and Poverty Reduction in China (Research Report 138, International Food Policy Research Institute, Washington D.C.) at 5.

6 Editorial, 2007. China's Income Disparity Grows. People's Daily Online (http://english.people.com.cn/english/200007/12/eng20000712_45330.html).

${ }^{7}$ China's legal system ranked in the $51^{\text {st }}$ percentile on the World Bank's rule of law index in 2002, having risen from the $32^{\text {nd }}$ percentile in 1996. The index is part of the World Bank's Report: Governance Matters V: Governance Indicators for 1996-2005: http://web.worldbank.org. This index measures the extent to which people have confidence in and abide by the rules of society, how fair and predictable the rules are, and how well property rights are protected. The indicators include perceptions of incidence of crime, the effectiveness and predictability of the judiciary, and the enforceability of contracts.

${ }^{8}$ For a more extensive treatment of legal reforms in China, see Randall Peerenboom. 2002. China’s Long March toward Rule of Law. New York: Cambridge University Press (discussing the differences between thin (procedural) and thick (substantive) theories of rule of law: 65-71). See also Stanley B. Lubman. 1999. Bird in A Cage - Legal Reform in China after Mao. Stanford. (Calif.: Stanford University Press); and 2006. Looking for Law in China. 20 Columbia J. of Asian L. 1-92. 
approach. ${ }^{9}$ The economy is still in transition from a centrally-planned economy towards a socialist market economy; it is highly fragmented and unevenly developed across the country. Economic development has preceded social development. There are many "pressure points" in Chinese society that, if not managed well, could potentially derail the train of economic reform. China has experienced remarkable economic growth apparently without the benefit of the "rule of law", ${ }^{10}$ which may present a problem for the law and development movement. ${ }^{11}$ The Chinese legal system features many "transplants" from other legal systems while retaining strong "Chinese characteristics". One area of such transplants is the income tax law applicable to foreign investors in China.

This paper examines the role of tax policy in China's development. Following the introduction, Part II outlines the current Chinese tax system and major episodes of tax reforms. It describes the current tax structure, context for tax reforms and tax policy objectives in order to provide the necessary background. ${ }^{12}$ Parts III to IV discuss the role of tax policy in China's economic development, social development, and legal

\footnotetext{
${ }^{9}$ Randall Peerenboom. 2006. What Have We Learned About Law And Development? Describing, Predicting, and Assessing Legal Reforms in China. 27 Mich. J. Int'l L. 823; Peerenboom, ibid, at 197.

${ }^{10}$ For a classic account of this movement see David Trubek and Marc Galanter. 1974. Scholars in Self-Estrangement: Some Reflections on the Crisis in Law and Development Studies in the United States. (4) Wisonsin L. Rev, 1062-1102. For recent literature on law and development, see Antony Anghie. 2000. Time Present and Time Past: Globalization, International Financial Institutions, and the Third World. (32) N.Y.U. J. Int' L \& Pol. 243; Anthony Carty. 1992. Law and Economic Development. New York, N.Y.: New York University Press; Ronald J. Daniels and Michael Trebilcock. 2004. The Political Economy of Rule of Law Reform in Developing Countries. (26) Mich. J. Int'l L. 99, at 102; and Kerry Rittich, 2004. The Future Of Law And Development: Second Generation Reforms And The Incorporation Of The Social. 26 Mich. J. Int'l L. 199 (this article has been included in David Trubek and Alvaro Santos, eds. 2006. The New Law and Economic Development (Cambridge UP).

11 See also Randall Peerenboom. 2006. "Is China a Problem Case? (603) Annals 192, at 192.

12 Alec Easson and Jinyan Li. 1989. Taxation of Foreign Investment in the People's Republic of China. De Hague. The Netherlands, Kluwer.
} 
development. The paper concludes with some general themes arising from the discussions.

\section{Chinese TAX System And Policy: AN OVERVIEW}

The Chinese tax system ${ }^{13}$ "looks" like other tax systems. It consists of income taxes, consumption taxes, property taxes and miscellaneous taxes. The functions of taxation are to raise revenue, to stimulate economic growth, and to facilitate social and political stability. The current system is the result of major reforms during the last three decades.

\section{A. HistORICAL EVOLUTION}

Soon after the Communist Party formed government in 1949 China initiated a socialist reconstruction of the economy. Private capital was “nationalized" and foreign investment gradually left China. Some turnover taxes and some property taxes were introduced and administered by the general tax bureau. The reconstruction was more or less complete in 1956. From 1956 to 1978, a strict Soviet-type command economy was practised and the private sector almost vanished. Industry and commerce were completely controlled by publicly owned enterprises. State-owned enterprises delivered all their profits to the government and turnover taxes were generally used to facilitate the transfer of funds from enterprises to the government's coffer. At the peak of the political and economic turmoil during the Cultural Revolution (1965-76), law and order was in disarray, the role of taxation was disregarded, and the tax department existed only in name.

\footnotetext{
${ }^{13}$ For an overview of Chinese tax system, see Easson and Li, ibid.; Donald J.S. Brean, ed., Taxation in Modern China. 1998. New York and London, Ruthledge; and Jinyan Li. 1991. Taxation in the People's Republic of China. New York. Praeger. For some historical account of the system, see George N. Ecklund. 1963. Taxation in Communist China (1950-59).Ann Arbor, Michigan. University Microfilms, Inc.
} 
In 1978, under the leadership of Deng Xiaoping, the Communist Party changed its policy from political struggle to economic development. ${ }^{14}$ Deng made it clear that the need for economic development prevailed over the concern about the pursuit of the Party's socialist ideals. "It doesn't matter if a cat is black or white, so long as it catches mice."15 The economic reforms thus changed the relationship between the state and the market, allowing room for tax policy design.

The new economic policy had two parts: opening up China to foreign investment and reforming the domestic economic system. Establishing a modern tax system was considered critical to the success of the policy. To facilitate the transition, a two-track tax system was introduced so that a Western style tax system would apply to foreign-invested firms and individuals and another system would apply to Chinese firms and citizens:

- The "foreign" track was created first: the Individual Income Tax (targeted at foreign individuals) (1980), the Equity Joint Ventures Income Tax (1980) and the Foreign Enterprise Income Tax (1981) (applicable to co-operative joint ventures, wholly foreign-owned enterprises and other foreign entities doing business in China). A multi-stage, cumulative turnover tax -Consolidated Industrial and Commercial Tax (1958) - was revived because it was the only "tax law" in existence. ${ }^{16}$

- The "domestic" track was created in 1983 and 1984: state enterprises became subject to taxes -- a reform which is commonly referred to in Chinese as li gai shui (taxation replacing profit delivery); separate taxes applied to the emerging collective enterprises and private enterprises; turnover taxes applicable to

\footnotetext{
${ }^{14}$ Sheying Chen. 2002. Economic Reform and Social Change in China: Past, Present, and Future of the Economic State. (15) No.4 Int'l J. of Politics and Society 569-89, at 572.

15 CNN. Reformer with an iron fist: Deng Xiaoping (1904-1997). http://www.cnn.com/SPECIALS/1999/china.50/inside.china/profiles/deng.xiaoping/.

${ }^{16}$ As explained under Part V below, "law" is a statute enacted by the legislation. China deemed it important to subject foreign investors to tax "laws", not just "interim regulations" or "administrative rules".
} 
domestic enterprise were introduced; and numerous miscellaneous taxes on property and transactions were reintroduced.

The years following 1986 saw the rationalization, consolidation, and reform of existing taxes. In 1991, the foreign track became consolidated: the Equity Joint Ventures Income Tax was merged with the Foreign Enterprise Income Tax to become the Enterprise Income Tax on Foreign Investment Enterprises and Foreign Enterprises (the "FIE Tax"). In 1994, the three domestic enterprise income taxes were replaced by a consolidated domestic Enterprise Income Tax. The foreign track merged with the domestic track in the area of turnover taxes and individual income tax. The 1994 reform also resulted in a new central-local tax assignment between the central and local government as well as a new system of tax administration. A new uniform Enterprise Income Tax Law was promulgated in on March 16, 2007 to replace the existing FIE Tax and domestic enterprise income tax. ${ }^{17}$

The evolution of the tax system generally tracks the development of the market conditions in China. When the market was just emerging in the 1980s, the government retained tight control over domestic enterprises and used tax policy to "regulate" these enterprises. In the 1990s, improving market conditions required more "neutral" tax policies and triggered the consolidation of taxes in 1994. China's accession to the World Trade Organization in 2001 and further economic reforms led to further deregulation of the economy. The Uniform Enterprise Income Tax symbolizes the ending of official "tax discrimination" against domestic enterprises and the government's confidence in "free competition" between domestic and foreign investors.

${ }^{17}$ Enterprise Income Tax Law of the People's Republic of China, promulgated by the $5^{\text {th }}$ Session of the Tenth National People's Congress, March 16, 2007. This law replaces the two existing enterprise income taxes as of January 1, 2008. 


\section{B. CURREnt TAX Structure}

\section{CONSUMPTION TAXES}

The Chinese terminology for consumption taxes are "turnover taxes" (liu zhuan shui), because, other than the VAT, tax is imposed on gross turnover. These taxes include the Value-added Tax (VAT), Business Tax, Consumption Tax, and Resources Tax. They generate more than twothirds of total tax revenue. ${ }^{18}$

The VAT is the most productive source of revenue - more than $37 \%$ of total tax revenue in 2004. ${ }^{19}$ This tax applies to the sale of goods and selected services. The standard rate is $17 \%$. A lower rate of $13 \%$ rate applies to necessities, certain culture products, agricultural supplies, and other goods as stipulated by the State Council. Exports are zero-rated. "Small suppliers" are taxed at 6 percent. One key feature of the Chinese VAT that distinguishes it from many other VAT systems is the scope of input credit. The Chinese VAT allows no input credit for the cost of fixed assets, such as computers, machinery and equipment, thereby resulting in cascading taxation on capital expenditures.

The Business Tax, which applies to gross turnover, is imposed on business activities that are not subject to the VAT - mostly services. The tax rate is $3 \%$ for transportation, construction, postal communication, cultural and athletic activities; 5\% for banking, insurance, services, and the transfer of intangible property and immovable property; and 5\% to $20 \%$ for entertainment (the applicable rate is determined by the local government).

The Consumption Tax, which also applies to gross turnover, is an excise imposed on the sale and importation of luxury goods, such as tobacco, liquor, cosmetics, fireworks and firecrackers, gasoline, diesel, tires, motorcycles and automobiles. The tax rates range from 3\% on non-luxury cars to $45 \%$ on top-quality cigarettes. This tax is imposed in addition to the VAT.

\footnotetext{
${ }^{18}$ China Statistics Yearbook 2005. Source: http://www.stats.gov.cn/tjsj/ndsj/2005/html/H0803e.htm.

19 Ibid.
} 
The Resource Tax is a turnover tax imposed on the production and sale of crude oil, natural gas, coal, non-ferrous metals, ferrous metals, and salt in China. The amount of tax payable is determined by the Ministry of Finance according to the mining or production conditions of the taxpayer.

\section{INCOME TAXES}

Income taxes are the second major source of revenue, generating about 22 percent of total tax revenue. ${ }^{20}$ Income taxes have been growing faster than consumption taxes. ${ }^{21}$ The dual-track system has been an important feature in enterprise income taxation.

Overall, the foreign track, or the FIE Tax, is more "western" as it addresses international issues and China wanted to follow the international tax norm. The domestic track has more features from the command economy and is much less detailed than the FIE Tax. For example, the FIE legislation contains over 19,418 words, the domestic enterprise income tax legislation contains only 9251 words. With respect to deductible expenses, FIEs may deduct the cost of wages, salaries and employee benefits whereas domestic enterprises can deduct only the amount of wages in accordance with the standard set by the government. The most notable difference lies in the tax preferences: tax preference provisions account for $1 / 20$ of the provisions in the domestic legislation, and $1 / 5$ provisions of the FIE Tax Law.

The Individual Income Tax is a schedular tax. Income from employment is taxed monthly at progressive rates ranging from 5\% to 45\% (CNY100,000 or US\$11,494). Income from the business of industrial and commercial activities and enterprise leasing and management are taxable annually at progressive rates ranging from 5\% to $35 \%$. Income from personal services

\footnotetext{
${ }^{20}$ Ibid.

${ }^{21}$ From 2000-2005, the overall growth rate is 20.1. The growth rate is $18 \%$ for VAT, 17.6\% for Business Tax, 13.6\% for Consumption Tax, 24.7\% for Domestic Enterprise Income Tax, $28.6 \%$ for FIE Tax, and 90\% for Individual Income Tax. See Source: China Statistics Yearbook, 2000 (for data related to 1994-99); State Administration of Taxation, "Growth of Each Taxes", http://www.chinatax.gov.cn/view.jsp?code=200603091136179494 (visited on April 14, 2006) (for data related to 2000-2005).
} 
is subject to a $20 \%$ flat rate tax. ${ }^{22}$ Investment income, incidental income, and capital gains are taxed at a flat rate of $20 \%$. In computing the taxable amount, a deduction for actual expenses is allowed only in the case of business income. A standard deduction is allowed in the case of employment income, income from services, rents and royalties. Interest, dividends, and incidental income are taxed on a gross basis. Tax is withheld at source in all cases other than business income.

\section{PROPERTY AND OTHER TAXES}

There is a large number of taxes on property, transactions, and other activities, generating about $8 \%$ of total tax revenue. ${ }^{23}$ Taxes on real estate are the most significant. A real estate gains tax was introduced in 1993 to regulate the growing real estate market in China. It applies to gains from the transfer of land-use rights, buildings (other than residential housing) and other structures affixed to land at progressive rates ranging from $30 \%$ to $60 \%$. The urban real estate tax is imposed on the owners of real estate in urban areas. The Deed Tax is levied on the transfer of land-use rights, the sale, gift or exchange of houses and buildings.

The Stamp Tax applies to the signing or issue of commercial contracts and documents. For example, loan contracts are taxed at $0.005 \%$ of the loan amount, and technology contracts are taxed at $0.03 \%$ of the contractual price. Taxpayers pay the tax by purchasing and affixing tax stamps.

\section{CENTRAl AND LOCAl FisCAL RELATIONSHIP}

China's political system is unitary. The financial system is highly decentralized as expenditures by local governments account for $71 \%$ of

\footnotetext{
${ }^{22}$ A surtax is applicable when a particular payment is "abnormally high" (i.e., exceeding CNY20,000). The surtax is imposed at the following rates: $10 \%$ on an amount between CNY20,000 and CNY50,000; 20\% on an amount exceeding CNY50,000. Therefore, the combined tax rate is $30 \%$ on taxable amount exceeding CNY20,000 (up to CNY50,000) and $40 \%$ on taxable amount exceeding CNY50,000.

${ }^{23}$ SAT, http://www.chinatax.gov.cn.
} 
government expenditures. ${ }^{24}$ This creates enormous challenges to Chinese tax policy. ${ }^{25}$ The Central Government has exclusive taxing powers in terms of legislation. All taxes are introduced by the Central Government. However, revenue from specific taxes is assigned to local government.

Under the current revenue-sharing system, local governments are entitled to the revenue from the following taxes: $100 \%$ of property and transaction taxes, ${ }^{26} 25 \%$ of VAT, Business Tax (with minor exceptions), domestic enterprise income tax (other than those paid by centrally-owned enterprises, local banks, financial institutions, and railway, banking and insurance companies that pay income tax centrally through their head office); FIE Tax (other than those paid by foreign banks); and Resource tax (other than those paid by offshore oil companies).

In general, sub-national governments receive about $50 \%$ of total tax revenue. $^{27}$ There is thus a structural shortage in local revenue, which has serious implications for development.

\section{Goals of Tax Policy Design}

In China, a paramount goal for tax policy design is to raise adequate revenue for the government to finance its ambitious reform programs. A subsidiary goal is to regulate private activities to facilitate the economic

\footnotetext{
${ }^{24}$ Source: Ministry of Finance: http://www.mof.gov.cn/news/uploadfile/zhongyang001.xls; http://www.mof.gov.cn/news/uploadfile/zhongyang0009.xls.

${ }^{25}$ Bahl, Roy W. 1999. Fiscal Policy in China. Taxation and Inter-governmental Fiscal Relations (South San Francisco: University of Michigan Press); Bahl, R.W. and Jorge Martinez-Vazquez. 2003. "Fiscal Federalism and Economic Reform in China", paper prepared for Fiscal Federalism in a Global Environment (Center for Research on Economic Development and Policy Reform, Stanford University.); Richard Bird and Duanjie Chen. 1998. Intergovernmental Fiscal Relations in China in International Perspective. in Donald J.S. Brean, ed., Taxation in Modern China (London and New York: Routledge), at 151-85.

${ }^{26}$ However, sub-national governments can get only $2 \%$ of Stamp Duties imposed on stock transactions.

${ }^{27}$ Local governments rely on fiscal transfers for additional revenue.
} 
transition. As discussed below, China has also been conscientious about using tax reforms to promote social stability and the idea of rule-by-law.

\section{REVENUE}

Reforms cost money. Fundamental reforms cost a great deal of money. Securing adequate revenue has been one of the most important concern in Chinese tax policy. During the past three decades, taxation has become a main source of government revenue. In recent years, tax revenues have been rising relative to GDP and in absolute terms. The tax/GDP ratio was $18.6 \%$ in 2003 and $12.6 \%$ in $1993 .^{28}$ The amount of tax revenue in 2003 was 5.4 times of that in $1993 .^{29}$

The current tax structure has been designed to generate maximum revenue. ${ }^{30}$ Most taxes in China are collected by the use of consumption taxes. Compared to income taxes, consumption taxes are easier to administer. These taxes are collected from enterprises, not consumers, thereby reducing the cost of administration and compliance. Turnover taxes had existed prior to economic reforms and Chinese enterprises were used to them. Even though the VAT was a new type of tax and the invoice-control system was more complex, VAT accounting and management are simpler than income taxes. ${ }^{31}$ The second major type of

${ }^{28}$ This ratio is much lower than that in OECD countries. See OECD (2002) China in the World Economy: The Domestic Policy Challenges (Paris, 2002).

\footnotetext{
${ }^{29}$ See Ministry of Finance, http://www.mof.gov.cn/news/uploadfile/guojia020.xls .
}

${ }^{30}$ In terms of growth, however, consumption-based taxes lag behind income taxation. Since 2000, the ratio has dropped to 68 percent when enterprise income taxes grew from $13.9 \%$ of total tax revenue in 1994 to $16.4 \%$ in 2004, and Individual Income Tax grew from less than 1 percent to 6 percent in 2004. With the maturity of the Chinese tax system, the share of income taxation in the tax structure is expected to increase even further. See Zhou, Quanlin and Wang Qiao. 2006. A Rational and Equitable Analysis of Chinese Government's Tax Collection Scope. No.1, Taxation Research J. 32-36 at 33 (in Chinese).

${ }^{31}$ Under the current circumstances, reliance on businesses for tax collection is arguably more efficient than relying on individuals. However, improving the transparency in tax policy making and in the relationship between tax payment and provision of public goods will certainly help improve the overall efficiency in tax collection. 
tax is income tax on business entities. Again, this tax is relatively easier to collect than individual income taxes.

\section{TAX INCENTIVES}

China has used tax incentives extensively. In tax jargons, these tax incentives are referred to as "tax expenditures." Tax expenditures are, in essence, the spending of money by the government by way of foregoing the taxes owed under the normal rules of tax law. They are the economic equivalence of the government receiving the taxes owed and then subsidizing the activity through a grant.

Every major tax law contains tax expenditure provisions. ${ }^{32}$ For example, the VAT exempts contraceptive medicines from tax. Business Tax exempts child care, education and medical services. The Individual Income Tax exempts a large variety of amounts from tax. They include awards from the government, settlement fees to military personnel, salary of foreign experts sent to work in China international organizations. The Foreign-investment Enterprise Income Tax provides a wide range of preferences to new enterprises, FIEs operating in special areas, ${ }^{33}$ FIEs exporting more than $70 \%$ of their products each year, and high-tech FIEs. $^{34}$ The standard 20\% withholding tax on dividends, interest, rents and

32 Shi Yaobin, 2004. Establishing a Tax Expenditure Administrative System That Achieves a Sound Fiscal System in China. in Hana Polackova Brixi, Christian M.A. Valenduc. And Zhicheng. L. Swifft, eds. 2004. Tax Expenditures-Shedding Light on Government Spending through the Tax System: Lessons from Developed and Transition Economies (Washington D.C. The World Bank) 173-189, at 177. There is no shortage of Chinese literature on tax expenditures, such as Tax Research Institute. 1992. Theory and Practice of Tax Expenditures; Lou Jiwei. 2003. Theoretical Innovations and Systematic Explorations in Tax Expenditure. Most of the literature is descriptive and some normative and critical of the current tax policies.

33 Special economic zones, Open Coastal Economic Zones, the Economic and Technological Development Zones, Shanghai Pudong New Area, industrial parks, bonded zones, and the Western Region. For a more detailed discussion of these preferences, see Jiang, Zhaodong. 1999. China's Tax Preferences to Foreign Investment: Policy, Culture and Modern Concepts. 18 NW. J. INT'L L. \& BUS. 549 at 601.

${ }^{34}$ In addition, the non-resident withholding tax on dividends, interest, rentals, royalties is either waived or reduced. For example, dividends paid by foreign-invested enterprises are currently exempt from withholding tax. Withholding tax is waived in the case of interest 
royalties may be waived or reduced, upon the approval of the tax administration.

Using tax expenditures as policy instruments is consistent with China's previous practice of "central planning", the autocratic style of governance, the need to accommodate local economic conditions of different regions of the country, and the desire to compete with other developing countries in attracting foreign direct investment (FDI). ${ }^{35}$ For example, international competitiveness has always been a key concern in Chinese tax policy. Although the nominal enterprise income tax rate is $33 \%,{ }^{36}$ the effective rate for FIEs is set at about 10 to 15 percent as a result of the tax expenditures. This is to ensure that the Chinese tax rate was close to the rate in Hong Kong, which has been the main source of FDI. Because Hong Kong does not tax foreign source business profits and Mainland China is a "foreign" jurisdiction, ${ }^{37}$ Chinese tax determines the total tax liability of Hong Kong investors. For investors from other countries, Chinese tax treaties generally contain a tax sparing credit to preserve the economic benefit of Chinese tax preferences to the investor. ${ }^{38}$

on loans extended to the Chinese Government or China's state banks by international financial organizations, interest on loans to China's state banks with preferential interest rates. Royalty withholding tax rate is reduced from the standard 20 percent to $10 \%$ or 0 if the technology is "advanced" and offered on "preferential" terms, and the technology is related to scientific research, the development of energy resources, transportation, communications, and production in agriculture, forestry, animal husbandry and fishing.

35 There is a strong sense expressed in the Chinese literature that well-designed tax incentives are important to economic development. While virtually every issue of International Tax Journal of China, Taxation Research, and China Taxation publishes articles on tax incentives, the author has not come across a single piece arguing that tax incentives are not useful to economic development.

${ }^{36}$ In order to maintain competitiveness, the nominal tax rate is set at $33 \%$ for enterprise income tax, which was comparable to the rates in China's neighbouring countries in the early 1980s.

37 Jinyan Li. 2003. International Taxation in the Age of Electronic Commerce: A Comparative Study (Toronto, Canadian Tax Foundation) ch.6.

${ }^{38}$ China's treaty policy also promotes the competitiveness of the Chinese tax system. Many of China's tax treaties waive or reduce source withholding taxes on investment income to top up the already generous domestic tax preferences. As a result, not only Chinese tax is low not only for FDI but also foreign passive investment. 
On the other hand, however, the extensive use of tax expenditures contradicts with the main goal of tax policy - generating revenue. Tax expenditures have a huge revenue cost. In the absence of any official estimate, ${ }^{39}$ an unofficial estimate put the figure at CNY50 billion per year, or up to $10 \%$ of local tax revenue in certain places. ${ }^{40}$ A more aggressive estimate put the amount of revenue loss equal to the amount of revenue collected: ${ }^{41}$

In terms of scale, the cost of current tax expenditures has reached-and even exceeded - the amount of total tax revenue collected by the benchmark system. For example, the cost of tax expenditures within the commodity tax nearly equals commodity tax revenue. Moreover, the cost of income tax expenditures exceeds the amount of income tax revenue.

This estimate presumably includes revenue loss resulted directly from the foregone taxes as well as losses resulted indirectly from misuse and abuse of tax expenditures and increased cost of administration and compliance. ${ }^{42}$

39 The Ministry of Finance is in the process of establishing a team of experts to study the issue of tax expenditures and develop models for assessments.

${ }^{40} \mathrm{Lu}$, Jiansuo. 1999. A Brief Discussion on the Sources of and Preventive Measures for Tax Revenue Loss. No. 9 Tax Research Journal 61-64 (in Chinese).

41 Ma Quoqiang. 2004. China’s Current Tax Expenditure System: Issues and Policy Options. in Brixi et al., supra note 32, 190-202 at 197. Chinese scholars have increasingly argued that the tax incentive regimes in China are generous to a fault. See for example, Chen Chun. 2005. Thoughts on China's Foreign Tax Incentives. (no.7) Int'l Taxation in China 31-33; Li Zhiyuan. 2006. Building A Tax Expenditure System Suitable for China, No.3, Taxation Research J. 40-42; Tang Zhiqiang. 2005. Defects and Adjustments of Foreign Tax Incentives. no.10, Int'l Taxation in China 26-27; and Ye Jun. 2005. Discussion of the Need to Keep or Abolish Foreign Tax Incentives. no.11, Int'l Taxation in China 28-29.

42 See, for example, Li, Zhiyuan. 2006. Building A Tax Expenditure System Suitable for China. No.3 Taxation Research 40-42; Li, Tingxu. 1999. Means of Tax Avoidance and Tax Evasion by Foreign Investment Enterprises and Prevention Measures. No.8 ,International Tax Journal of China 62-64; Tie Wei. 1999. Causes and Assessment of Tax Avoidance under Current Tax System. No.11 Int'l Taxation in China 32-34; Zhang, Yiming and Zhang Xiaoting. 2005. Issues of VAT Type-Conversion. No.8 Tax Research Journal 22-23 (discussing how enterprises in the North-East region take advantages of the 


\section{REGULATORY INSTRUMENT}

In addition to providing economic stimulations through tax incentives, tax policy plays a strong regulatory role in China. Some of the taxes used to be called "regulatory taxes" or "adjustment taxes" as they were introduced for the main purpose of regulating private activities. For example, the Regulatory Tax on Fixed Assets Investments was introduced in 1991 "to implement state industry policy, to control the scale of investment, to guide the direction of investment, to adjust the structure of investment, to strengthen construction of major projects, and promote sustainable, stable, coordinated economic growth". ${ }^{43}$ Tax rates range from nil to $30 \%$ (e.g., detached residential houses or cottages built with public funds).

Real estate taxes and stamp duty are often used to "cool down" the overheated real estate or stock market by raising tax rates. For example, when the government tripled the stamp duty on securities transactions late in the evening on May 30, 2007, it sent the stock markets into a tailspin that saw the benchmark Shanghai Composite Index drop roughly 20\% through midday Tuesday before it turned upward again. ${ }^{44}$

\section{ECONOMIC DEVELOPMENT}

This part discussive assessment of the relationship between tax policy and China's economic development. More specifically, it focuses on tax policy in respect of enterprise income taxation and foreign direct investment. It notes the extent to which tax policy was driven by developmental features of the Chinese economy, i.e., transitional, favoring foreign direct

new VAT credit for capital expenditures); and Ye, Jun. 2005. To Repeal or Not to Repeal of Foreign Tax Incentive Policies. No.11 International Tax Journal of China 28-29 (all in Chinese).

${ }^{43}$ Regulations on the Regulatory Tax on Fixed Assets Investment, State Council Directive, [1991] No.82, article 1.

${ }^{44}$ Shu-Ching Jean Chen. 2007. Beijing Denies Capital Gains Tax In The Works. http://www.forbes.com/markets/2007/06/07/china-capital-gains-markets-econ-

cx_jc_0607markets1.html (visited June 8, 2007). 
investment, and regional disparities. It draws some preliminary conclusions about the negative impact of certain tax policies on economic development. Overall, the relationship is dynamic and mutually reactive.

\section{A. TAx POLICY In A TRAnsitional ECONOMY}

Generally speaking, tax policy has a direct impact on economic development by either leaving the market alone or interfering with it. In tax jargons, these are the policy of tax neutrality and the policy of tax expenditures. These policies ostensibly contradict each other, although both could be defended on the ground of economic development.

The principle of tax neutrality requires a tax system be "designed to bring about a minimum change in the allocation of resources within the private sector of the economy." ${ }^{45}$ The reason underlying this principle is that "at least in the present state of knowledge, the allocation of resources in response to free market forces will in general give in the short run the best utilisation of resources, and in the long run the most satisfactory rate of increase in the output of the economy." ${ }^{, 46}$ In a neutral tax system, people's work practices and business and investment decisions would be no different than they would have been in a world without taxes. To the extent that behaviour is influenced by the tax system, there is a taxinduced change in the allocation of society's resources; that is the effect of a tax system that is not neutral.

Despite all the arguments in favour of neutrality, the government of most countries use tax policy to pursue various social and economic policies, often using deductions from income or credits against tax as the means of providing the desired incentive.

As mentioned already, the Chinese tax system is full of tax incentives. The typical justifications for tax expenditures include: market failures, positive externalities of certain activities, and efficiency in delivering social programs through tax subsidies as opposed to direct spending programs. They can all be invoked in China. The fact that the Chinese economy has

\footnotetext{
${ }^{45}$ Report of the Royal Commission on Taxation (Carter Report) (1966), vol. 2, 8.

${ }^{46}$ Ibid.
} 
been undergoing a transition from a centrally-planned model to a market model makes a prima facie case for tax expenditures on ground of market failures. Attracting foreign direct investment through tax incentives is justified because such investment generates a large number of benefits to China, such as job creation, capital market developments, management skills, and exports of China-made products. However, the development of the market economy has demanded, and to some extent, been facilitated by, a neutrality-oriented tax policy. From a historical perspective, tax neutrality has gained ground over tax expenditures. Since China's accession to the World Trade Organization (WTO) in 2001, tax neutrality has become a main objective of tax reform. As such, the relationship between tax policy and economic development in China is relative to the stage of economic transition.

\section{B. DUAL-TRACK TAX SYSTEM AND ECONOMIC REFORMS}

Until the 1994 tax reform, the Chinese tax policy was designed to be differential in order to stimulate certain economic activities under “imperfect” market conditions. As such, tax policy played a positive role in facilitating the economic transition.

One differential tax policy is the dual-track enterprise income tax system: foreign enterprises and foreign-invested Chinese enterprises were taxed under one regime, whereas pure domestically-owned enterprises were taxed under a different regime. Overall, the foreign-track allowed more tax incentives, lower tax burdens. This policy seemed to have contributed positively to the success of economic reforms at earlier stages. The domestic track was considered highly successful in complementing the structural reforms of state-owned enterprises (SOEs). A main goal in internal economic reforms was to restructure SOEs to become economically efficient entities. Replacing the previous profit-delivery mechanisms under the command economy with tax payments helped SOEs and their government regulators to recognize the new relationship between the enterprises and the government. It also provided economic incentives for SOEs to be more profitable as they can keep the after-tax profits. The tax system brought some "objective" assessment of the 
performances of SOEs. ${ }^{47}$ Another goal in internal economic reforms was to gradually allow the development of the private sector, which was previously viewed suspiciously in ideological terms. ${ }^{48}$ By taxing the profits of private enterprises the government legitimized the private sector.

The foreign track of the tax system was deemed necessary in order to create a more enticing environment for foreign investors. During the early periods of economic reforms, there were significant market failures and the internal tax policy had strong traits of the command economy. Maintaining a separate tax regime for foreign investment enterprises (FIEs) was possible because FIEs were expected to invest in China and export products to the world market. Direct competition with local enterprises on the Chinese market was limited. FIEs were allowed in selected sectors of the economy, mostly manufacturing Within the approved sectors, FIEs were regulated more by market principles than government plans. China became a huge base for manufacturing and exports. Judging from the growth of FDI in China (growing from a total of USD 4,104 million from 1978-1984 to USD60,630 million in 2004 alone), ${ }^{49}$ it is easy to see why the Chinese government believed that such policy goal has been met.

However, the external and internal reforms are not wholly independent of each other. When the market conditions develop for domestic enterprises and FIEs began to face fewer regulatory hurdles to enter the Chinese market, competition between domestically-funded and foreign-funded enterprises intensified. Since China's accession to the WTO in 2001, China has further reduced barriers for FDI. For example, foreign firms have been gradually allowed to own up to 50 per cent of enterprises in sensitive industries, such as telecom and insurance industries. Foreign importers have been allowed to own domestic distribution networks, and foreign banks will be able to conduct local currency business with Chinese enterprises within two years of accession. During the past few years,

\footnotetext{
${ }^{47} \mathrm{Li}$ (1991), supra note 13.

${ }^{48}$ Huang, Yasheng. 1999. Selling China: Foreign Direct Investment During Reform Era (Cambridge: Cambridge University Press) at 331.

${ }^{49}$ China Statistical Year Book (2005). http://www.stats.gov.cn/tjjj/ndsj/2005/html/R1813e.htm (in Chinese).
} 
China is no longer just a manufacturing base for multinational corporations, but a marketplace for products and services. Apparently, among the sectors open to FDI, the top five enterprises in each sector have become controlled by foreign investors, and foreign investors control the majority of assets in 21 out of 28 major industrial sectors. ${ }^{50}$

Given China's conditions (size, uneven regional development, and transitional nature of the economy), China's long-term growth must depend on a well-developed market for all investors. The effective tax burden on FIEs is about 5 per cents lower than that for SOEs. ${ }^{51}$ The twotrack tax policy has recently been considered to be unfair, ${ }^{52}$ resulting in inefficient allocation of resources. Chinese-owned enterprises have been crying for "national treatment" from their own government. ${ }^{53}$

50 Shi, Weigan. 2006. A Reexamination of the Role of Foreign Investors. http://finance.sina.com.cn (September 1, 2006) (in Chinese)

51 Tax Policy and Legislation Department of State Administration of Taxation, ed. 2003. Frontier Tax Policy Study in China (Beijing, China Tax Press) (in Chinese).

52 See, for example, Tang, Zhiqiang. 2005. Foreign Tax Preferences: Defects and Adjustments. No.12 Int'l Taxation in China 26-27 (in Chinese).

${ }^{53}$ In addition to the dual-track enterprise income taxation, some other features of Chinese tax structure are considered by Chinese scholars to impede economic development. One example is the production-type VAT which denies an input credit for capital expenditures. The lack of credit presumably discourages enterprises from investing in machinery and equipment and from becoming technology-intensive or capital-intensive enterprises. Because capital expenditures are not deductible, input taxes embedded in exported products cannot be fully refunded to the exporter, thereby discouraging exports. On the other hand, the export-refund system under the VAT, which is consistent with WTO principles, is believed to have promoted China's export growth. China's heavy reliance on VAT in its tax structure allows China to subsidize exports at a greater degree than a tax system that relies more on income taxation. As regulatory instruments, the Consumption Tax and Resources Tax are considered to have played a positive role in discouraging the consumption of luxury goods and the excessive use of natural resources. The levy of transaction-based taxes, such as Stamp Duties, Deeds Tax, and real estate taxes may have played a role in "cooling" down the over-heated real estate market and in saving China from the Asian financial crisis in the late 1990s. 


\section{TAX PREFERENCES FOR FDI}

Foreign direct investment (FDI) was considered crucial to China's economic development because FDI is often accompanied by the badlyneeded technology, management skills, and international market information. ${ }^{54}$ At the inception of the economic reforms, tax preferences played a positive role because of their potential signalling effect, the compensation effect, and the hospitality effect. ${ }^{55}$ In the late 1970s, China relied on tax preferences as part of its overall strategy to attract foreign direct investment. ${ }^{56}$ The intention was to send a clear signal to foreign investors China's desire for capital from abroad. This signalling effect is historically important because China suffered from serious image problems due to its previous policies that were hostile to foreign investors. The choice of the very word in the Chinese language, "you hui" (preferences) conveyed a positive message. This message was widely disseminated and viewed as a key to the success of efforts to promote foreign investment.

${ }^{54}$ Huang, Yasheng. 2003. The Benefits of FDI in a Transitional Economy: The Case of China. in New Horizons for Foreign Direct Investment (Paris: OECD).

55 For more discussion on these effects, see Caves, Richard E. 1996. Multinational Enterprise and economic analysis (Cambridge: Cambridge University press); Dunning, John. 1988. Investment Incentives throughout Asia. in Explaining International Production (London: Unwin Hyman); Dunning, John. 1993. Multinational Enterprises and the Global Economy (New York: Addison-Wesley); Janeba, Eckhard. 2002. Attracting FDI in a Politically Risky World. 43 (4) International Economic Review 1127-55; Porcano, Thomas and Charles E. Price. 1996. The Effect of Government Tax and Nontax Incentives on Foreign Direct Investment. (4) Multinational Business Review 9-19; Rolfe, Robert J. and Richard A. White. 1992. Investors' Assessment of the Importance of Tax Incentives in Locating Foreign Export-Oriented Investment: An Exploratory Study. (14) The J. of the American Taxation Association 39-57; Rondinelli, Dennis, and William J. Brupitt. 2000. Do Government Incentives Attract and Retain International Investment? A Study of Foreign-Owned Firms in North Carolina. 33 (2) Policy Sciences 181-205; and Single, Louise. 1999. Tax Holidays and Firm's Subsidiary Location Desires. 21 (2) The J. of the American Taxation Association 17-34.

56 This promise was first made in the 1979 Equity Joint Venture Law, which was the first piece of legislation governing FDI since the inception of reforms. Just as punitive rates under the previous system were the legacy of policies that reflected past hostility toward foreign and private capital, in new Equity Joint Venture Law was testament to a favourable policy change. 
FDI location decisions are influenced by the characteristics of host countries, such as endowment of natural resources and labour, level of economic development, macroeconomic conditions as well as the institutional environment in terms of property rights protection and government policy creditability. During the early years of economic reforms, China had weak property rights institutions or the system of rule of law and relatively low creditability. Therefore, offering generous tax preferences arguably compensated China's weaknesses in this respect. ${ }^{57}$

Offering generous tax preferences to foreign investors is also consistent with the Chinese hospitality and respects for friendship and personal relationships. Tax preferences were presented as gifts or rewards to overseas investors. ${ }^{58}$ The Confucian way of dealing with foreigners was to be "generous with gifts without calculating the value of tribute and to grant them honours without making heavy demands." ${ }^{59}$ The Chinese believed that by showing generosity and hospitality they could exert moral influence on non-Chinese and lead them to "participate in the benefits of (Chinese) civilisation." ${ }^{60}$ The grant of tax preferences is associated with the Chinese respect or dependence on relationships (or "guanxi" in Chinese) because exchanges of gifts are an important practice in establishing and retaining relationships. Whether foreign investors actually came to China or even expressed an interest in doing business with the country, the Chinese claimed them as friends. Investors could interpret tax preferences as reciprocation for their friendly acts of investing in China. ${ }^{61}$ This relationship-building effect of tax preferences may have a special appeal to overseas Chinese investors. Some of them may have been affected by the Communist Party's previous harsh policies and may regard

\footnotetext{
${ }^{57}$ This is consistent with the findings by Li, Quan. 2006. Democracy, Autocracy, and Tax Incentives to Foreign Direct Investors: A Cross-National Analysis. 68 (1) The J. of Politics 62-74 (more democratic regimes have more creditable rule of law and as a result are associated with lower levels of incentives).

${ }^{58}$ Zhaodong Jiang. 1998. China’s Tax Preferences to Foreign Investment: Policy, Culture and Modern Concepts. 18 NW. J. Int'l L. \& Bus. 549 at 611.

${ }^{59}$ Ibid., at 618.

${ }^{60}$ Ibid.

${ }^{61}$ Ibid., at 630 .
} 
gestures such as granting preferential treatment as implied apologies and compensation for past ill-treatment. Some overseas Chinese have a strong attachment to their ancestral land and returned to their native villages and hometowns for sentimental as well as business reasons. They felt welcome when local government presented them with gifts, including tax preferences. $^{62}$

The tax preferences presumably played an important role in attracting overseas Chinese investors. Much of the Chinese FDI inflow consists of capital from three ethnically Chinese economies: Hong Kong, Taiwan, and Macao. ${ }^{63}$ FDI from these three sources accounted for 59.3 per cent of China's total FDI inflows between 1978 and 1999. ${ }^{64}$ Ethnic Chinese capital suppliers in Asia, North America and other parts of the world also contributed to the rapid growth of FDI in China.

However, these signalling, compensation and hospitality effects wore off as China's investment conditions improve over time. Arguably, China does not need to rely on tax preferences to lure investors to China because China is now known to have a huge internal market, cheap and disciplined labour force, and relatively stable political and legal regime. Meanwhile, the tax preferences cause serious distortions to investment for several reasons:

1. As mentioned already, they create unfair tax treatment of domestic and foreign enterprises.

2. They encourage the "wrong" type of investment. The majority of tax preferences are granted for "new" investment, they do not promote long-term commitment. Foreign investors who are

\footnotetext{
${ }^{62}$ Ibid. This emphasis on building relationships through gift exchanges created some problems. Local officials preferred to broad powers in granting tax preferences and to outperform other local officials in competing for the investment, resulting in regional tax competition and disregard of centrally-made tax policy.

${ }^{63}$ For example, the Ministry of Commerce of China list the top ten origins of FDI in China to be Hong Kong, Virgin Islands, Japan, South Korea, United States, Taiwan, Cayman Islands, Singapore, Germany and Western Samoa for the first half of 2005.

${ }^{64}$ Huang (1999), supra note 48, at 36.
} 
committed to China may create a new entity to benefit from the tax preferences instead of investing in an existing enterprise.

3. To the extent that tax preferences did result in attracting FDI, because the lion's share FDI is in special areas and regions in South-Eastern China, they worsen the problem of regional disparities. $^{65}$

4. Instead of attracting real "foreign" capital, the generous tax preferences encourage Chinese indigenous capital to take an international "round trip" 66 before investing in China. The round tripping distorts data on FDI in China, which may not only influence the effectiveness and official management of China's FDI utilization, but also bring risks to China's financial system. ${ }^{67}$ The People's Daily ${ }^{68}$ reported:

The British Virgin Islands is a major destination for China's offshore investment. ... 10,000 out of 500,000 companies there are from China. Most China-originated money entering tax havens will reenter China as "foreign investment," -- "round tripping". ... A closer examination of China's star foreign direct investment (FDI) figures reveal a large amount of capital going out of the country and returning under a different guise. The World Bank and other experts have estimated the scale of this

\footnotetext{
${ }^{65}$ Chen, Chun (2005) "Reflections on the matter of Foreign Tax Preferences" Int'l Taxation in China No.7, 31-33 (in Chinese).

${ }^{66}$ The World Bank and other agencies and experts have estimated that the scale of this round tripping could be as high as a quarter of the total FDI inflows into PRC: World Bank (2002), Global Development Finance 2002: www.worldbank.org. For more discussion, see Xiao, Geng. 2004. Round-T ripping Foreign Direct Investment in the People's Republic of China: Scale, Causes and Implications. http://www.adbi.org/discussion-paper/2004/06/01/450.prc.foreign.direct.investment.

${ }^{67}$ Ibid.

68 "Investment outflows to tax havens" June 22, 2004. http://english.peopledaily.com.cn/200406/22/eng20040622_147138.html.
} 
round tripping could be as large as 20 per cent to 30 per cent of the total FDI inflow into China, but there is no clear definition and detailed estimation method behind the numbers. ... Even worse is that the trend is growing bigger. ... The biggest pay-off for recycling mainland-originated money through a web of companies offshore is the tax concessions that China grants to foreign firms.

5. As one of the largest FDI recipients in the world, China's preferential tax regime for FDI presumably increases the use of tax havens, resulting in "harmful" tax competition. ${ }^{69}$ FDI from wellknown tax havens accounts for the lion's share of FDI in China. ${ }^{70}$ For example, FDI from Virgin Islands is almost twice as much as that from the United States; FDI from Samoa (a Pacific island country) is about twice as much as FDI from Australia; and more FDI from Mauritius than that from South Africa. ${ }^{71}$ Therefore, while the tax preferences may not have increased the total FDI in China once the signalling effect, the compensation effect and the hospitality effect become less important, there is no doubt that the Chinese tax regime influences how FDI is channelled to China.

${ }^{69}$ It is beyond the scope of this paper to discuss the implications of the Chinese tax regime for the "harmful tax competition" debate.

${ }^{70}$ For a list of origins of FDI, see China Statistical Year Book (2005). http://www.stats.gov.cn/tjsj/ndsj/2005/html/R1815e.htm.

${ }^{71}$ On August 8, 2006, the Ministry of Commerce ("MOFCOM"), joined by the Stateowned Assets Supervision and Administration Commission of the State Council, State Administration of Taxation, State Administration for Industry and Commerce, China Securities Regulatory Commission ("CSRC") and State Administration of Foreign Exchange, amended and released the Provisions for Foreign Investors to Merge and Acquire Domestic Enterprises. These include new provisions geared at deterring "false" foreign investment. These provisions include: where a PRC entity establishes an offshore company for the purpose of acquiring a related domestic company, the post-acquisition company will not enjoy FIE treatment unless foreign investors - other than the PRCcontrolled entity - hold $25 \%$ or more of the post-acquisition company, or (ii) the offshore company invests additional capital accounting for at least $25 \%$ of the post-acquisition company's total capital. 


\section{TAX REFORM TOWARDS NEUTRALITY}

The promulgation of the new Uniform Enterprise Income Tax Law ${ }^{72}$ signals a shift of Chinese tax policy towards neutrality and fairness. The uniform tax rate of 25 percent applies to all enterprises, irrespective of their ownership. Tax preferences earmarked for FIEs are to be phased out in five years. Tax incentives are redesigned to subsidize all "high-tech" companies and companies that invest in equipment for environmental protection and water conservation and production safety.

Investors and capital markets in China welcome the new tax law as they expect the big domestic companies - the major banks, telecom companies, oil and gas producers - that dominate indexes of Chinese stocks, will see their after-tax earnings boosted by the tax change. ${ }^{73}$ Chinese tax policy makers maintain that the new law will have minimal negative impact on attracting FDI to China. ${ }^{74}$ The overall $25 \%$ tax rate is competitive with neighbouring countries. The grand-fathering rule for existing foreigninvested enterprises will help smooth the transition.

\section{SOCIAL DEVELOPMENT}

\section{A. SOCIAL DEVELOPMENT LAGGING}

China's development goal is to build up a "Xiaokang society" in which "people generally are not rich but have adequate food, clothing, and other material belongings necessary for a decent life."75 Economic development is a precondition for reaching this goal. ${ }^{76}$ Amid its rapid economic

${ }^{72}$ Supra note 17.

${ }^{73}$ Andrew Batson. 2007. China's Expected New Tax Law would Even the Playing Field. The Wall Street Journal (February 26, 2007), at C9.

${ }^{74}$ Xinhua. 2006. China fosters fair competition with unified tax rate. People's Daily Online: http://english.people.com.cn/200612/29/eng20061229_336969.html.

${ }^{75}$ UNDP. 2005. China Human Development Report 2005. http://www.undp.org.cn at 1.

${ }^{76}$ This is not much different from the "Asian path" to development: Pareerboom (2005), supra note 8. In 2005, however, the new leadership put forward the concept of scientific development and the concept of harmonious society to guide reforms. This was the first 
growth, China has achieved social development in certain areas. For example, according to the United Nations report, China's human development index improved continuously in the past 20 years, from 0.557 in 1980 to 0.755 in 2003 and China's global ranking rose from 101st in 1991 to 85th in 2003.77 On the other hand, there have been increasing income disparities, regional disparities, and urban and rural disparities. For example, in 2002, per capita GDP in East China was CNY12,266, but only CNY5,144 in Southwest. Within the Southwest region, urban per capita GDP was CNY6,304, and rural per capita GDP was only CNY1,744. ${ }^{78}$ Women, children, and racial minorities are generally disadvantaged disproportionately. Tax policy has not played any significant role in promoting social development and in redistribution.

\section{B. The TAX Mix And InCOME RedistRibution}

The tax structure in China cannot, by design, play a key role in alleviating inequality in income and wealth. In developed countries, the income tax, especially the personal income tax, has been used as the main instrument for redistributing income. ${ }^{79}$ In China, the Individual Income Tax's role of redistribution remains largely symbolic at the moment. ${ }^{80}$ This tax accounts

time that China took a more comprehensive approach towards development. Social development is elevated to complement economic development. The concept of harmonious society stresses the need to reconcile conflicts between rural and urban areas and between different social groups to promote social stability. It is linked to the notions of social welfare and more equal income distribution and to the rule of law. This new comprehensive approach has not been reflected in tax policy. This part of the paper examines the relationship between tax policy and social development. See National People's Congress. 2005. Report on the Work of Government Third Session, $10^{\text {th }}$ National People's Congress and Chinese People's Political Consultative Conference, March 5, 2005.

${ }^{77}$ UNDP (2005), supra note 75 , at 7.

${ }^{78}$ Fan and Chan-Kang (2005), supra note 5, at 8.

${ }^{79}$ See Richard M. Bird and Eric M. Zolt (2005). "The Limited Role of the Personal Income Tax in Developing Countries” (52) UCLA L. Rev. 1627, at 1627.

${ }^{80}$ This is not much different from the role of personal income tax in other developing countries. See Bird and Eric Zolt, ibid. 
for about $6 \%$ of total tax revenue. ${ }^{81}$ It is progressive only with respect to employment income and business income as other types of income are taxable at a flat rate. The fraction of population paying the tax grew from $0.1 \%$ of all wage earners in 1986 to $32 \%$ of all wage earners in $2001^{82}$ and the average amount of annual tax paid by each wage earner was CNY314 (less than USD40) in 2002. ${ }^{83}$ More than one-third of the total IIT on employment income was collected from workers at FIEs. ${ }^{84}$ Given the current situations in China, the Individual Income Tax cannot be a meaningful tool of redistribution. ${ }^{85}$

The VAT and turnover taxes have some progressive features. For example, the Consumption Tax is imposed on luxury goods and services at progressive rates. This tax is presumably borne by high-income earners. ${ }^{86}$ The VAT is slightly progressive with a lower rate on certain necessities (e.g., grain and edible oil, running water). Overall however, these taxes worsen the urban/rural disparities as low-income rural residents much pay

${ }^{81}$ Although still an insignificant source of revenue for the government, the amount of revenue increased rapidly: it grew by more than 6 times between 1980 (CNY0.1 million, accounting for less than 1\% of total tax revenue) and 2004 (CNY173,700 million): see State Administration of Taxation, Tax Statistics, published on its website: www.chinatax.gov.cn (visited on April 20, 2006).

${ }^{82}$ Thomas Piketty and Nancy Qian.2004. Income Inequality and Progressive Income Taxation in China and India, 1986-2001. http://globetrotter.berkeley.edu/macarthur/inequality/papers/PikettyQian2004.pdf at 9-10. This fraction is expected to drop as a result of the increased standard deduction to CNY1600. See Jinyan Li. 2006. Chinese Individual Income Tax: A 26-Year Old Infant. Tax Notes Int’l (July 24, 2006) 297.

${ }^{83}$ Shi, Hua. 2004. Changes in the IIT Revenue Composition. No.4 China Taxation 4-6 (in Chinese).

${ }^{84}$ Frontier Tax Policy Study in China (2003), supra note 51, at 344.

${ }^{85}$ Some Chinese scholars argue that progressive taxation cannot achieve distributive justice. See, for example, Wang, Chunling and Huang Shumin. 2005. Can Progressive Taxation Realize Distributive Justice? No.10 China Taxation 41 (in Chinese) (the authors argue that progressive taxation does not change the inequality in the process of distribution of income, provides disincentive to investors and savers, and distorts market allocation of resources).

${ }^{86}$ The practice of exchanging gifts in business dealings also means that businesses also purchase luxury products as gifts and deduct the cost of the gifts as business expenses. 
these taxes. In many poor rural areas, these taxes are the only taxes collected. $^{87}$

The lack of progressivity in the Chinese tax system disproportionately disadvantages women and children. In China, women make up a smaller proportion of the white-collar workforce than men, and ratio of female-tomale earnings is about $0.82 .^{88}$

\section{SOCIAL TAX EXPENDITURES}

Compared with the wide variety of tax preferences for economic development, tax expenditures for social development are fewer in number and less in amount. ${ }^{89}$ Most of the tax expenditures under the IIT relate to disaster relief, family planning, payments to military personnel, and retired cadres. These measures are largely reactive to other policy decisions and are not designed to promote any social activities.

${ }^{87}$ Tao Ran and Mingxing Liu. 2005. Urban and Rural Household Taxation in China: Measurement, Comparison and Policy Implications. (10) No.4 J. of the Asia Pacific Economy 486-505.

${ }^{88}$ UNDP (2005), supra note 75, at 43. The regional disparities and shortage of financial resources at the local level also have significant adverse impact on women and ethic minority groups. Ethnic minority groups generally reside in less developed regions. The lack of resources at local level often results in lack of funding for hospitals, schools, housing, etc. Thus, local service providers have to charge. Local schools, for example, now have to charge what are high fees for peasants. This has led to a dramatic shift in education opportunities for women in rural areas. A son is the future "pension plan" for his parents; a daughter is someone's wife and will help support the husband's parents. Thus, in the rural areas and minority areas where the one-child policy is not strictly applied, and the daughter is often required to work to pay for the schooling of her brother. The results are striking -the ratio of women to men going on to higher education is shifting significantly. In rural areas, one study found that girls' overall enrolment rates was about $83 \%$, compared with $92 \%$ for boys' rates. Girls in the bottom household income quintile had enrolment rates of 75\%. See Emily Hannum, 2003. Poverty and Basic Education in Rural China: Villages, Households, and Girls' and Boys Enrollment. (47) No.2 Comparative Education Review 141 at 153. On average, with adult population, the illiteracy rate of females is 2.6 times that of males: UNDP (2005), supra note 75, at 49.

${ }^{89}$ Ma, supra note 41. 
Arguably, tax expenditures on social development are as important as those for economic development during the economic transition. At the time of increasing income gaps, the economic reforms smashed the "iron rice bowl" style of social security (which was tied to lifetime employment at a work unit) when state-owned enterprises were transformed into “economically efficient” entities. Redundant workers lost their jobs as well as their welfare system (which is typically consisted of subsidized housing, medical insurance, and old age pensions). ${ }^{90}$ The government has not introduced any meaningful tax subsidies for housing, education, charitable donations, child care, medical care, family support or retirement savings. No specific tax expenditure is designed to create jobs or workers training or relocation. Although the government has been flirting with the idea of tax-subsidized enterprise annuities (or occupational pension plans), as discussed below, no concrete tax policy has been enacted.

Retirement income security is a significant social and political issue in China. The Chinese population is aging at an accelerating speed owing to three possible factors: the baby-boom in the 1950s and 1960s; the "singlechild per family" policy, resulting in a 4-2-1 family structure featuring 4 grandparents, two parents, and one child; and the increasing longevity of the Chinese people. The percentage of individuals aged 60 and older in the Chinese population was 10 percent in 1999 and is expected to be 20.42 percent in 2030. $^{91}$ All this means that there will be fewer young people in the future to pay taxes that can adequately support the elderly.

Since the early 1990s, the Chinese government has regarded enterprise annuities (employer-sponsored pension plans) as an important pillar in the pension system and tax policy as a key instrument for supporting enterprise annuities. $^{92}$ Enterprise annuities are expected to supplement the

90 For an excellent discussion of how state-owned enterprises were both "economic entities” and social welfare providers, see Chen. 2002. supra note 14.

91 By 2030, retirees will account for more than $40 \%$ of workers. The Chinese population is also aging faster than others. For example, the percentage of retirees (65 years and older) of the population grew from 7 to 14 percent in 115 years in France, 66 years in the United States, and only 25 years in China.

92 In 2000, the State Council confirmed that enterprise annuities should take the form of defined contribution plans and be managed in accordance with market principles: State Council's Notice on the Plan for the Trial Implementation of Perfecting the Social 
public pension pillar, which is designed to provide a basic pension of up to 40 or 45 percent of the average salary at the time of retirement. The capital market welcomed the development of enterprise annuities. It is estimated that pension funds in China could exceed US\$160 billion by 2030 and become the world's third largest pension market. ${ }^{93}$ Many enterprises created annuities for their workers in order to attract and retain workers in an increasingly competitive labour market. The government introduced regulatory measures in $2004^{94}$ to require that all annuities plans be defined contribution plans and be managed in accordance with market principles. The Ministry of Finance has not enacted any companion tax measures to clarify this issue, although a tax deduction was contemplated by the government. ${ }^{95}$ Under the existing tax legislation, contributions made by an enterprise into a privately-funded pension plan are generally not deductible. ${ }^{96}$ Borrowing the metaphor from Professor Graetz, ${ }^{97}$ enterprise

Insurance System in Cities and Townships”, Guo Fa [2000] No.42. Some local governments introduced their own rules to regulate enterprise annuities. By 2004, most of the enterprise annuity plans were established by firms in Shanghai, Shenzhen, Dalian and other coastal cities that have enjoyed rapid economic growth as well as national enterprises in the railway, electricity, petroleum, chemical and financial sectors. The annuity funds were managed by local social security administration or the sponsoring enterprise. See Jinyan Li. 2005. Enterprise Annuities and Tax Policy in China: Engaged, but Not Yet Married. (59) 12 Bulletin for Int'l Fiscal Documentation.

93 Liu, Yunlong, and Fu, Pingan. 2004. Enterprise Annuity: Model Options and International Comparison, at 1 (in Chinese).

94 MOLSS. Trial Measures on Enterprise Annuities (hereafter "Enterprise Annuity Rules”), January 6, 2004, with effect from May 1, 2004. See also, MOLSS. Operating Rules governing the Management of Enterprise Annuity Fund. December 31, 2004; Standardization of Information Systems for Management of Enterprise Annuity Fund Accounts. December 31, 2004; Expert Assessment Rules for Certifying the Status of Institutions for Managing Enterprise Annuity Funds. December 31, 2004;

MOLSS, China Banking Regulatory Commission, China Securities Regulatory Commission, and China Insurance Regulatory Commission. Trial Measures on the Management of Enterprise Annuity Funds,” February 23, 2004 with effect from May 1, 2004 (hereafter “Enterprise Annuity Fund Management Rules”).

${ }^{95}$ In a State Council document entitled "Plan for the Trial Implementation of Perfecting Social Security System in Cities and Townships” [Guo Fa [2000] No.42.], enterprises could deduct up to $4 \%$ of total salary.

96 Some local governments have introduced their own tax measures to allow the deduction, ranging from 4 percent to 8 percent, or more of the total salary. For example, 
annuities and tax policy were engaged to be married for the past fifteen years. And yet, the formal marriage has not taken place.

\section{LEGAL DEVELOPMENT}

\section{A. SySTEM OF RULE-BY-LAW}

China has never had a Western style democracy. The Chinese legal system does not contain even the "minimalist content of rule of law"98 - that is, a regime under which "the government acts according to the rules produced in the political arena and respects the civil rights of its citizens, and that there is a judicial party to resort to that embodies the ethic of treating all cases before it neutrally and fairly." The current Chinese legal system is one of "shehui zhuyi fazhi guojia", ${ }^{100}$ or "socialist rule-by-law." The preamble of the Constitution states that China will be guided by

in Jiangsu Province, a sponsoring employer can deduct an amount of contributions up to 1.5 month of the salary cost of its employees: Jiangsu State Tax Bureau, and Jiangsu Local Tax Bureau, Su Guo Shui Fa [2003] No.147, and Su Di Shui Fa [2003] No.163. See also Guangdong Province, "Notice on Establishing Enterprise Annuities in Guangdong Province” Yue Fu Ban, [2004] No.81, August 16, 2004 (http://www.szpf.gov.cn).

${ }^{97}$ Graetz, Michael J. 1987. The Troubled Marriage of Retirement Security and Tax Policies. (135) U. Pa. L. Rev. 851.

${ }^{98}$ For an excellent survey of the notion of "rule of law" in the context of development, see Daniels and Trebilcock, supra note 10. For more discussion about whether China has rule of law, see Donald C. Clarke. 2003. Puzzling Observations in Chinese Law: When Is a Riddle Just a Mistake? in C. Stephen Hsu., ed. 2003. Understanding China’s Legal System (NYU Press), at 93-121; Randall Peerenboom R, 'Competing Conceptions of the Rule of Law in China' in Peerenboom R, (ed), 2004. Asian Discourses of Rule of Law (Routledge, London) at 113-145; Peerenboom. 2002. Let One Hundred Flowers Bloom, One Hundred Schools Contend: Debating Rule of Law in China' (3) No.6 Perspectives 7; Wang, J. 2004. The rule of law in China: A realistic view of the jurisprudence, the impact of the WTO, and the prospects for future development. (2004 December) Singapore Journal of Legal Studies 347.

${ }^{99}$ Daniels and Trebilcock (2004), supra note 10, at 104.

${ }^{100}$ In 1999 the Constitution was amended to state in article 5: “The People’s Republic of China shall practice ruling the country according to law, and shall construct a socialist rule-of-law state". 
“Marxism-Leninism, Mao Zedong Thought, Deng Xiaoping Theory” and that "the Chinese people of all ethic groups will continue to adhere to the people's democratic dictatorship and the socialist road”. Article 3 of the Constitution requires all state organs (including the court) to apply "the principle of democratic centralism.”

Under the system of rule-by-law, law is made at the top and implemented by government agencies. Governmental actions are, in turn, regulated by detailed rules. In recent years, Chinese laws and regulations are becoming increasingly detailed and transparent. A culture of rule-by-law is taking root in the Chinese bureaucracy as it is widely recognized as key to maintaining social order and stability. ${ }^{101}$ The economic transition calls for a legal regime that can provide adequate regulation for market players, coordinate different kinds of interest, and provide order and predictability in human affairs. ${ }^{102}$ The lack of any precedence in regulating a market economy made it necessary for the Chinese government to learn from the West. As mentioned at the beginning of this paper, however, the Chinese government refused any whole-sale importation of western legal regimes. China has adapted western laws to suit Chinese political, social and economic conditions. For example, the Chinese tax system and tax rules look similar to those in western countries. The major differences between the Chinese tax system and western tax systems lie in how the tax legislation is made and interpreted.

It is beyond the scope of this paper to discuss whether the lack of rule-oflaw has impeded development in China or whether China's legal system has directly contributed to China's economic development. ${ }^{103}$ What

${ }^{101}$ Gary H. Jefferson. 1997. China’s Economic Future: A Discussion Paper. (8) no.4 J. of Asian Economics 581 at 583.

102 Albert H.Y. Chen. 1999. Toward a Legal Enlightenment: Discussions in Contemporary China on the Rule of Law. (17) no.2 \& 3 UCLA Pac. Basin L. J. 125 at 137.

103 For a discussion of legal development in other areas, see Clarke, Donald. C., Peter Murrell, and Susan Whiting. 2005. The Role of Law in China's Economic Development. http://ssrn.com/abstract=878672. In this paper, the authors examine whether law plays an important role in three spheres of activity-property rights, agreements to trade, and corporate governance. They note that there have been profound changes, with law 
follows is a discussion of the development of a rule-by-law in the Chinese tax system and a normative argument that such development has played a positive role in China's overall legal development.

\section{B. RULES-BASED TAX SYSTEM}

\section{LAW-MAKING}

In China, tax legislation includes tax "laws" ("fa lu") enacted by the National People's Congress (the legislature), ${ }^{104}$ "administrative regulations" (fa gui) promulgated by the State Council (the government branch), ${ }^{105}$ as well as administrative rules introduced by the State Administration of Taxation (SAT), which is a ministry of the State Council. $^{106}$ At present, China has 3 existing tax laws (namely, the Individual Income Tax Law, the FIE Tax Law to be replaced by the new

playing an increasingly important role, and that formal legal institutions have not made a critical contribution to China's remarkable economic success.

104 The National People's Congress (NPC) is the supreme body under the Chinese Constitution. It meets once a year in Beijing. Most of the laws are passed by the Standing Committee of the NPC. The NPC often delegates legislative powers to the government (i.e., the State Council or ministries of the State Council). This power is exercised through the control over its members (the majority of members of NPC and high-ranking government bureaucrats are members), as well as through making policy decisions. In practice, the Communist Party controls the law-making process as most members of the NPC are Communist Party members who are required to follow the party direction.

105 The State Council is the most powerful organ of state in China. It has power to administer and enforce the legislation enacted by the NPC or NPC Standing Committee. It is also a legitimate law-making body on its own. Chinese Law-Making Law recognizes the force of law of "administrative regulations" by the State Council, as well as administrative rules introduced a ministry of State Council, such as the Ministry of Finance or State Administration of Taxation. More importantly, because Chinese legislation is drafted in broad language and provide broad discretionary powers to the administration, the government can often extend or modify the law in practice.

106 See Law-Making Law of the People’s Republic China, NPC, 2003. In principle, a lower-level form of legislation must not deviate from higher-level forms of legislation. In practice, many detailed rules of interpretation and application are specified in administrative rules or administrative regulations. “Administrative Rules” are documents issued by the departments of State Council, including the Ministry of Finance and State Administration of Taxation. 
EIT Law as of January 2008, and the Tax Administration and Collection Law $^{107}$ ), about 30 administrative tax regulations, about 50 administrative rules. ${ }^{108}$ Court decisions do not have the force of law in China. ${ }^{109}$ There is a long tradition of this style of law-making in China. ${ }^{110}$ Since the 1980 s, tax legislation has become more detailed and comprehensive. The trend is to elevate "administrative rules" to "administrative regulations" or tax laws.

\section{SUBSTANTIVE RULES}

Since 1980, there has been an immense increase in the number of tax laws and rules. Each tax law has become more detailed. For example, the new uniform Enterprise Income Tax Law has 5422 words, whereas the Join Venture Income Tax Law of 1980 had fewer than 2000 words. Each tax law is supplemented by a vast body of interpretative rules issued by the tax administration.

\footnotetext{
${ }^{107}$ This law was first introduced on April 21, 1986 by the State Council in the form of provisional regulation. On September 4, 1992, it was upgraded to "law" promulgated by the National People's Congress Standing Committee. Subsequent amendments were made on February 28, 1995 and April 28, 2001.

${ }^{108}$ The Taxation Science Research Institute of the State Administration of Taxation of China. 2005. Study on China's Taxation Legal System (Beijing, China Tax Press) at 3 (in Chinese).

109 The Chinese judiciary is very different from its counterpart in Western countries. Under the Constitution, the People's Court is subordinate to the NPC, not independent from it. The court has no independent power to interpret legislation. Most judges are party members. Courts at provincial and lower levels are part of the local governments.

110 There is a long tradition of this style of law-making in China. See William Alford. 1985. The Limits of "Grand Theory" in Comparative Law. (61) Wash. L. Rev. 945; Daniel Chow. 2003. The Legal Systems of the People’s Republic of China, (Thompson West), ch.2; Thomas Stephens. 1992. Order and Discipline in China (Seattle: University of Washington Press); William C. Jones. 2003. Trying to Understand the Current Chinese Legal System. In Hsu, C. Stephen, ed., Understanding China's legal system: essays in honor of Jerome A. Cohen (New York : New York University Press), 7-45; Graham Mayeda. 2005. A Normative Perspective on Legal Harmonization: China's Accession to the WTO. (38) U.B.C. Law Rev. 83; and Xin Ren. 1997. Tradition of the Law and Law of the Tradition (Greenwood Press).
} 
These tax rules provide an increasing degree of certainty to taxpayers with respect to the determination of their tax liability. Overall, the tax system is more and more based on relatively precise legal rules as opposed to openended standards or administrative discretions.

\section{TAX PROCEDURES AND ADMINISTRATION}

The SAT is responsible for administering tax laws in China. Instead of being part of the Ministry of Finance, the SAT is a separate department under the State Council. Its national head-office is in Beijing and local offices located across the country. Local tax bureaus were established to collect local taxes and some taxes shared between the national and local government. Local tax bureaus are part of local government, but under the supervision of the SAT in terms of tax law interpretation and policy. As of 2005 , there were over 747,200 individuals officially employed by the SAT and local tax bureaus. ${ }^{111}$

The tax administration is increasingly governed by rules and procedures. Tax collection and administration had been governed by administrative regulations until 1991 when The Tax Administration and Collection Law (TACL) was promulgated. The TACL contains 94 articles and modernizes the current collection system, sets clear standards on the collection of taxes at both the state and the local level, and sets penalties for various violations of the law. It also provides the framework to allow the tax authorities more access to taxpayer information and to better define the rights and responsibilities of both tax officers and taxpayers. The Implementation Rules for the TACL ${ }^{112}$ contain 113 articles, providing detailed implementation guidance for the supervision and administration of tax collection in China. The TACL and the Implementation Rules have

${ }^{111}$ SAT website, www.chinatax.gov.cn (visited June 18, 2007).

${ }^{112}$ Implementation Rules for the Tax Administration and Collection Law were enacted by the State Council on August 4, 1993, amended in 2002 to take effect on October 15 of that year. For an overview of the Implementation Rules for the TACL, see Daniel K.C. Cheung. 2002. Implementing Rules for Levying And Collecting Taxes In China. 28 Tax Notes Int'l 1141 (Dec. 16, 2002). 
been accredited not only as a "breakthrough in China's tax administration system, but a first in the history of China's legal system". ${ }^{113}$

In addition to TACL, there are rules governing invoice management, tax administrative reviews, tax audit, internal inspection, assessment of tax penalties, and tax litigation. The tax administration has also achieved remarkable progress in services, transparency and respect of taxpayers' rights.

At the beginning of economic transitions, the direct assessment system was necessary as taxpayers were unfamiliar with tax laws. With the deepening of the transition, direct assessment was gradually replaced by taxpayer reporting. By 1997, a three-part administration system was established: filing of returns by taxpayers coupled with taxpayer services, utilization of information technology, and centralization of tax collection and targeted tax audit and inspections. Taxpayers file tax returns at tax service centers. Tax collectors are no longer directly involved in establishing a taxpayer's tax liability. There are less "face-to-face" contact between taxpayers and tax officials who assess their tax liabilities, and thus fewer opportunities for dishonest taxpayers and tax collectors to collude in cheating on the tax system. Taxpayer services have been improving. Tax officials are required to "smile at taxpayers" or just "be nice and polite to taxpayers by putting themselves in the shoes of taxpayers." computerization and information technologies. Opportunities for corruption have been reduced greatly after the computerization of taxpayer records and initial selection of targets for audit.

The level of transparency in the tax administration improved greatly over the years. During the early years of reform, many tax documents were labelled as "confidential", out of reach to taxpayers. Now, the SAT publishes tax legislation, interpretation documents, rulings, and other

\footnotetext{
${ }^{113}$ Ibid., at 1145.

114 Shenzhen Local Tax Bureau. 1996. Strengthening the Service Function and Establishing Modern Tax Administration System in the Sepcial Economic Zone. Zhongguo Shuiwu, 1996, No.10, 5; Zhang Zilu, Guo Fengxiao, Liu Xiaoqing. 1996. Open a New Sky and Land. No. 7 Zhongguo Shuiwu, 15-19 (in Chinese).
} 
types of information on its website ${ }^{115}$ or in print form through the China Taxation Press. ${ }^{116}$ The SAT is also developing an advance ruling system, especially in the area of transfer pricing. The process of negotiating advance pricing agreements is governed by "Implementation Rules for Advance Pricing Agreements governing Transactions between Associated Enterprises (Trial)". ${ }^{117}$

Taxpayers' rights are specified in the TACL Law and Implementation Rules. ${ }^{118}$ Taxpayers (and withholding agents) have the following rights: to request that the tax authorities treat the information provided as confidential; to apply for tax reductions, exemptions, and refunds according to the relevant tax laws; to make a statement or to defend themselves against the decision of the tax office; to resort to the process of administrative and judicial review and to request compensation for damages incurred; and to use and disclose illegal activities conducted by the tax authorities and tax officials. ${ }^{119}$ In addition, taxpayers have the right to deny a tax inspection if tax officials fail to present a tax inspection

${ }^{115}$ http://www.chinatax.gov.cn.

${ }^{116}$ Publications includes books, loose-leaf, 6-volume Tax Laws and Regulations of the People's Republic of China, tax journals such as China Taxation, and Taxation Research, and news bulletins.

${ }^{117}$ Guo Shui Fa (2004) 118, 3 September 2004. Because the APA program is modelled on that recommended by the OECD and used in the United States, Canada and other OECD countries, the Chinese APA program is largely similar to that in OECD countries. For a discussion of the Chinese APAs, see IBFD. The International Guide to Transfer Pricing (loose-leaf) (chapter on China written by Jinyan Li) (Amsterdam, The Netherlands) (last update 2007).

118 The TACL also set forth taxpayers obligations. For example, taxpayers must complete tax registration. Without proper tax registration, taxpayers cannot open any bank accounts, apply for tax refunds or exemptions, or engage in tax matters relating to business cessation, business suspension, and the like. Taxpayers must keep proper books, vouchers, invoices, tax payment records, and other tax related information for at least 10 years. Taxpayers much install and use tax control equipment (such as computers with approved software). See TACL Implementation Rules, Articles 18, 28 and 29.

119 TACL, Art.8. 
certificate and tax inspection notice ${ }^{120}$ and to request an extension to file returns and to make tax payments. ${ }^{121}$

Tax officials are required by the TACL to be independent and impartial in enforcing tax laws, to act with integrity and courtesy, to respect and protect the rights of taxpayers and withholding agents, and to avoid conflicts of interest when carrying out collection or investigation. If taxpayers' rights are unlawfully infringed or violated, taxpayers can sue for damages. Tax officials may be sued for inappropriate conduct, such as the withholding or seizing of taxpayers' accommodation (such as residential property), daily living necessities in enforcing tax collections, or abuse of power. ${ }^{122}$ There are penalties on tax officials who show favouritism, commit malpractice, or fail to report criminal acts to law authorities or retaliate against taxpayers for reporting tax officials' wrongdoing as well as those who intentionally delay, advance, or allocate revenue quota or who wrongfully collect taxes.

There is a growing profession of tax practitioners to assist taxpayers in tax planning, compliance, and dispute resolution. At present, tax practice is dominated by accountants; on average, 30 percent of revenue of accounting firms is from tax work. ${ }^{123}$ Lawyers are engaged in tax practice, but on a much smaller scale. ${ }^{124}$ There are also over 62,000 certified tax agents, including 20,000 active practitioners ${ }^{125}$ who assist taxpayers with

${ }^{120}$ TACL, Art. 59; TACL Implementation Rules, Art.89.

${ }^{121}$ TACL, Arts. 27, 31 and TACL Implementation Rules, art. 37.

122 TACL, Art. 43.

${ }^{123}$ Study on Chinese Taxation Legal System (Beijing, China, 2005), supra note 108, at 394.

${ }^{124}$ Chow, supra note 109, at 229. For a discussion of the Chinese legal profession and legal education, see Wang, Weifang. 2005. China's Legal Profession: The Nascence And Growing Pains Of A Professionalized Legal Class. 19 Colum. J. Asian L 138; and Zeng, Xianyi. 2002. Legal Education in China. 43 S. Tex. L. Rev. 707.

125 See Xinhua, China Has 62,000 Certified Tax Agents. available http://www.chinadaily.com (2005-02-22 16:21). These agents are regulated by Trial Measures on Tax Agents issued by the SAT in September 1994 and Trial Rules Governing the Practice of Tax Agents issued by the SAT in October 2001. 
compliance, dispute resolution, and other dealings with the tax administration.

\section{THE COURT}

Under the Chinese Constitution, the judiciary is under the leadership of the National People's Congress. The courts have no independent power of interpretation of the law. ${ }^{126}$ There is no common-law tradition in China and judicial decisions do not form part of "law" in China. Judges are government officials in terms of salary, ranking, and appointment.

In the tax area, until recently, the courts played virtually no role. At present, the court's role is largely limited to adjudicating "administrative cases" and criminal cases. Administrative tax cases involve taxpayers bringing a law suit against a tax official or agency for "misconducts" in accordance with the Administrative Procedures Law. ${ }^{127}$ These conducts are generally related to actions in assessing penalties, enforcing collections, or other aspects of tax administration. Criminal cases involve tax payers and tax officials being prosecuted for tax fraud, evasion and other crimes.

The kinds of tax disputes dealt with by the tax court in countries such as Canada are rarely within the jurisdiction of Chinese courts. Disputes between taxpayers and the tax administration arising from the interpretation of tax legislation are mostly resolved through administrative

\footnotetext{
${ }^{126}$ It is beyond the scope of this paper to discuss the factors that hinder the development of judicial independence. For more discussion, see Peerenboom (2002), "The Judiciary: In Search of Independence, Authority and Competence" in China’s Long March Towards Rule of Law, supra note 8, Ch.7.

127 The Administrative Procedure Law of the People's Republic of China, adopted on April 4, 1989 at the Second Session of the Seventh National People's Congress. The SAT has issued guidelines to help local tax offices prepare for the defense, make arguments in court, file appeals, and enforce court decisions. See Operational Guidelines on Responding to Tax Administrative Appeals (effective on January 1, 1995). See also Decision of the SAT on Several Questions Concerning Establishing Displinary and Inspection Offices, Zhongguo Shuiwu Bao, November 15, 1995.
} 
reviews. ${ }^{128}$ The judiciary's role is very limited for several reasons. First, the courts do not have the final power of interpretation. The law-maker is also the interpreter in China. ${ }^{129}$ As such, the legislature, the State Council, or even the SAT has the power to interpret the meaning of tax legislation. ${ }^{130}$ It is largely pointless for tax payers to challenge the SAT's interpretation in a court. Moreover, Chinese tax law is largely administrative law. The SAT has de facto power to draft tax legislation, interpret it, and enforce it. Most Chinese taxes are governed by regulations or rules introduced by the State Council or the SAT. The SAT has the power of interpretation in most cases. Even with tax laws enacted by the NPC, the legislation is generally worded, leaving the tax administration with broad powers of interpretation. For example, with respect to entitlement to tax preferences, tax law generally requires taxpayers to apply to the tax administration for "approval" before they can enjoy the preferences. Finally, tax expertise is concentrated in the tax administration. Tax officials are presumed to know tax laws better than anyone else (taxpayers, judges, and members of the Legislature). The small number of tax cases makes it difficult for judges to develop tax expertise. There is a lack of institutional competence on the part of the judiciary to deal with tax law interpretation. Establishing a national

\footnotetext{
${ }^{128}$ Yao Meiyan and Hao Ruyu, at 663-669. See Study on Chinese Taxation Legal System (2005), supra note 108, at 277. Judicial appeals on matters of interpretation are virtually non-existent in China: Study on Chinese Taxation Legal System (2005), supra note 108, at 275 .

${ }^{129}$ This principle is consistent with the rule-by-man tradition in imperial China and the current "people's democratic dictatorship" model of governance endorsed by the Chinese constitution.

${ }^{130}$ The power of interpreting tax law is, in theory, shared among the legislature, the court, and the tax administration. In the case of statutes enacted by the legislature, the Standing Committee of the National People's Congress has the sole power to interpret "laws". The Supreme People's Court has the power to interpret the taxing statutes for the purposes of adjudicating cases. In practice, the Supreme Court has not heard any tax cases, so it has never rendered any interpretation. In tax evasion or tax fraud cases that involve the death penalty, the Supreme Court may be involved. In other case, courts of the second instance, usually the intermediate courts, render final decisions.
} 
travelling tax court ${ }^{131}$ would be helpful to the development of tax expertise in the judiciary, but such idea is unlikely implemented in the near future.

\section{TAX-DRIVEN DEVELOPMENT TOWARD RULE OF LAW}

Overall, compared to other areas of law in China, tax law is arguably the most sophisticated in terms of legislative drafting and administration. This is largely due to the importance of taxation to the government.

As explained earlier, China's primary tax policy objectives are revenue, efficiency and international competitiveness. Establishing a system of taxation based on clear rules is important to achieving these objectives because tax rules are written not only to govern the relationship between taxpayers and the government, but also the relationship between the SAT and local tax offices and the relationship between the tax administration and other government departments.

In terms of promotion of economic development, predictable and clear tax rules are undoubtedly important. Taxpayers need these rules to arrange their affairs or decide whether to invest in China. One of the reasons behind the dual-track enterprise income tax system was to create a tax system that is perceived to be predicable and fair by international investors. As discussed already, the dual-track system is highly discriminative now, but its original rationale was sound in the 1980s. China has always been sensitive to its international image and creating a rule-based system is considered to an important part of projecting a positive image. This sensitivity helps explain why the foreign track of the tax system (i.e., the Individual Income Tax and the FIE Tax) is regulated by taxing statutes enacted by the NPC.

In order to secure revenue, the SAT has worked hard to introduce rules to clarify the obligations and rights of taxpayers (discussed above) as well as those of local tax offices, other government agencies. The head-office of the SAT does not actually collect any taxes, the SAT requires clear tax

131 See, Xu, Shanda. 2003. Research on China's Taxing Powers (Beijing, China Tax Press). Mr. Xu is currently deputy commission of SAT. He used to be the head of the department of tax policy and tax legislation at the SAT. 
rules to guide and monitor the work of local offices. Clear rules also enable the SAT to fence off the interference of local governments with tax collection. In principle, "national" taxes are collected by the local offices of the SAT, and local taxes are collected by local tax bureaus. For example, income tax owed by state-owned enterprises under the control of the Central Government is collected by the SAT, while other types of domestic enterprises pay tax to the local tax bureaus. Under the previous central planning model, enterprises were managed by different level of governments. This legacy is continued into the current tax system. Since there is only a weak supervisory role of the SAT and there is no effective system for distributing and enforcing common policy, the SAT sometimes has to rely on more clear and authoritative legislative rules to carry out its policies.

In order to ensure productive cooperation between the SAT and other government departments (such as the police, the People's Bank, and the courts), the TACL specifically provide the obligations of these agencies in enforcement. In the absence of legislative rules, departmental conflicts or non-cooperation could be a serious problem. The lack of support from the police has been a main reason for the SAT to request a special "tax police" force. In order to regulate departmental relations, the rules must come from a superior body - the State Council or the NPC. That is why the TACL is one of three pieces of taxing statues enacted by the NPC.

A relatively sophisticated rules-based tax system might become a driving force towards the rule of law in China. Like taxpayers elsewhere, Chinese taxpayers will demand more protection of their private wealth ${ }^{132}$ and demand more certainty and predictability in their tax relationship with the government. The government will need to rely on more precise rules to improve governance in tax administration.

\footnotetext{
${ }^{132}$ The recognition and protection of "private property" has been affirmed by the newlypromulgated Property Law - Property Law of the People's Republic of China, promulgated on March 16, 2007 by the fifth session of the tenth People's Congress.
} 


\section{CONCLUSIONS}

This paper analyzes the role of tax policy in China's development. It concludes that tax policy has played an important, but somewhat mixed role in economic development. The current tax structure, emphasizing consumption taxation, is easier to administer and a reliable source of revenue. Tax incentives played an important role during the earlier years of economic development by helping attract FDI to China and restructuring domestic enterprises. In recent years, however, the negative impact of the tax incentives and the discriminative policy against domestic enterprises has become more serious. As an instrument of social development, tax policy has not been used much in China. Redistribution of income is minimal. Social spending through tax expenditures is insignificant. The relationship between legal development and tax policy is perhaps not as obvious. The paper argues that there has been significant development towards a tax system ruled by law. While the legislature and the judiciary play a limited (although gradually increasing) role in the tax system, the power of making, interpreting and enforcing tax rules largely remains with the tax administration. The Chinese tax administration has become more efficient, professional and transparent and recognizes a wide range of taxpayers' rights.

It is clear that tax reform has been an important part of legal reform in China, which in turn is an important part of China's development process. These reforms have aimed at creating substantive and procedurally efficient rules as opposed to creating a rule of law system, featuring an independent judiciary or an extensive system of civil liberties. ${ }^{133}$ The best tax policy is one that suits local conditions. Chinese tax policy is largely "home-grown", although international influences are important. During the early years, Chinese officials and scholars translated and studied foreign tax materials and learned from international tax experts. Through treaty negotiations, tax officials learned the fundamental rules of international taxation from their counterparts. International institutions,

${ }^{133}$ It is a paraphrase of Posner, ibid. at 9: "Legal reform is an important part of the modernization process of poor countries, but the focus of such reform should be on creating substantive and procedurally efficient rules of contract and property rather than on creating a first-class judiciary or an extensive system of civil liberties.” 
such as the IMF, OECD and World Bank, provided technical tax advice and training. The Chinese have insisted on "using foreign stuff to meet Chinese needs." VAT is good, but only production-type VAT is suitable to China. So, China opted for the not-so-good type of VAT. Self-assessment system is theoretically good, but impractical for China. So, the IIT is collected monthly through source withholding. China has not limited itself to learning from any particular regime of western laws (i.e., common-law or civil law).

Development is a universal issue, but the path to development may be country-specific. The Chinese model of development may be quite unique. The approach to development is "gradual" and pragmatic, not the "big bang" model adopted in other transitional economies. The style of governance is top-down - the government has a huge role in economic development. Ultimately, everything is political - all reforms have taken place within the confines of "socialism" and the leadership role of the Communist Party. This model of development defines the particular model of tax policy in China. 